\title{
THE DETERMINATION OF SODIUM IN BODY FLUIDS BY THE GLASS ELECTRODE*
}

\author{
BY EDWARD W. MOORE† AND DONALD W. WILSON \\ WITH THE TECHNiCAL ASSISTANCE OF ROBERT A. WALL, RICHARD E. LEBLANC, \\ AND MARTHA B. SWIFT
}

(From the Medical Services of the Lemuel Shattuck Hospital, Department of Public Health, and the Department of Medicine, Harvard Medical School, Boston, Mass.)

(Submitted for publication June 8, 1962 ; accepted November 8, 1962)

The use of glass electrodes for the determination of $\mathrm{pH}$ is well established. The possibility of measuring alkali ions in biological fluids by an electrode potential offers several advantages over other physical methods such as flame photometry (2). Since the publication of work by Eisenman, Rudin, and Casby (3) in 1957 demonstrating that the ternary glass system $\mathrm{Na}_{2} \mathrm{O}-\mathrm{Al}_{2} \mathrm{O}_{3}-\mathrm{SiO}_{2}$ may be systematically varied to produce electrodes with high affinity for selected cations, principally sodium and potassium, interest in such glasses has become widespread. These authors found no indication of glass poisoning by constituents of serum, cerebrospinal fluid, or brain homogenate, the electrodes showing expected potentials with known concentration changes of $\mathrm{Na}^{+}, \mathrm{H}^{+}, \mathrm{K}^{+}$, or $\mathrm{Ca}^{++}$.

Bower (4) found that sodium concentration of irrigation waters and saturation extracts of soils as determined by the electrode agreed closely with those obtained by flame photometry. Friedman and associates have demonstrated the ability of electrodes to follow cyclic changes of sodium concentration in mixed sodium and potassium solutions (5) and in whole blood (6), and Hinke (7) has constructed microelectrodes for the measurement of intracellular sodium and potassium activities.

To date, however, there has been no detailed report on the use of such glasses in biological fluids, or upon the accuracy with which such measurements may be made as a routine clinical

\footnotetext{
* Investigation supported in part by research grant A-2331 from the National Institute of Arthritis and Metabolic Diseases. A preliminary report of these studies has been published (1).

$\dagger$ Fellow of The Medical Foundation, Inc. of Boston. Work performed during tenure of a U. S. Public Health Service research fellowship of the National Institute of Arthritis and Metabolic Diseases.
}

or research tool. The purpose of this report is to provide such data for sodium ion by using a sodium aluminum silicate glass. Corroborating data will also be presented for a lithium analog glass. It will be shown that sodium activity (and concentration) may be rapidly determined in urine, serum, cerebrospinal fluid (CSF), whole blood, and plasma with a high degree of accuracy and reproducibility. Electrode response as a function of biological variables such as $\mathrm{pH}$ and temperature is the subject of a subsequent report (8).

\section{THEORETICAL CONSIDERATIONS}

Since the technique employed embodies the mathematical and electrochemical theories used in the determination of $\mathrm{pH}$, a brief review of the subject is pertinent to the present investigation.

Although the theory of the glass $\left(\mathrm{H}^{+}\right)$electrode has not yet been completely elucidated, its action appears to be related to the transfer of ions through the glass (9). The subject has been extensively reviewed by Dole (10) and more recently by Eisenman (11). The electromotive force (E) obtained with a $\mathrm{pH}$ electrode depends upon the difference in hydrogen ion activities across the glass membrane, and may be expressed by (12):

$$
E=E^{0}+\frac{2.3 R T}{n F} \log _{10} a_{m}{ }^{+}
$$

where $E^{0}$ is constant for a given electrode, $n$ is the valency of the ion, and $a_{m}{ }^{+}$is the activity of the cation in the test solution.

Since the measured e.m.f. (electromotive force) varies with the logarithm of $a_{m}{ }^{+}$, only small changes in e.m.f. are produced by large changes in $a_{m}{ }^{+}$. For any univalent cation such as sodium, the expected change in e.m.f. for a 


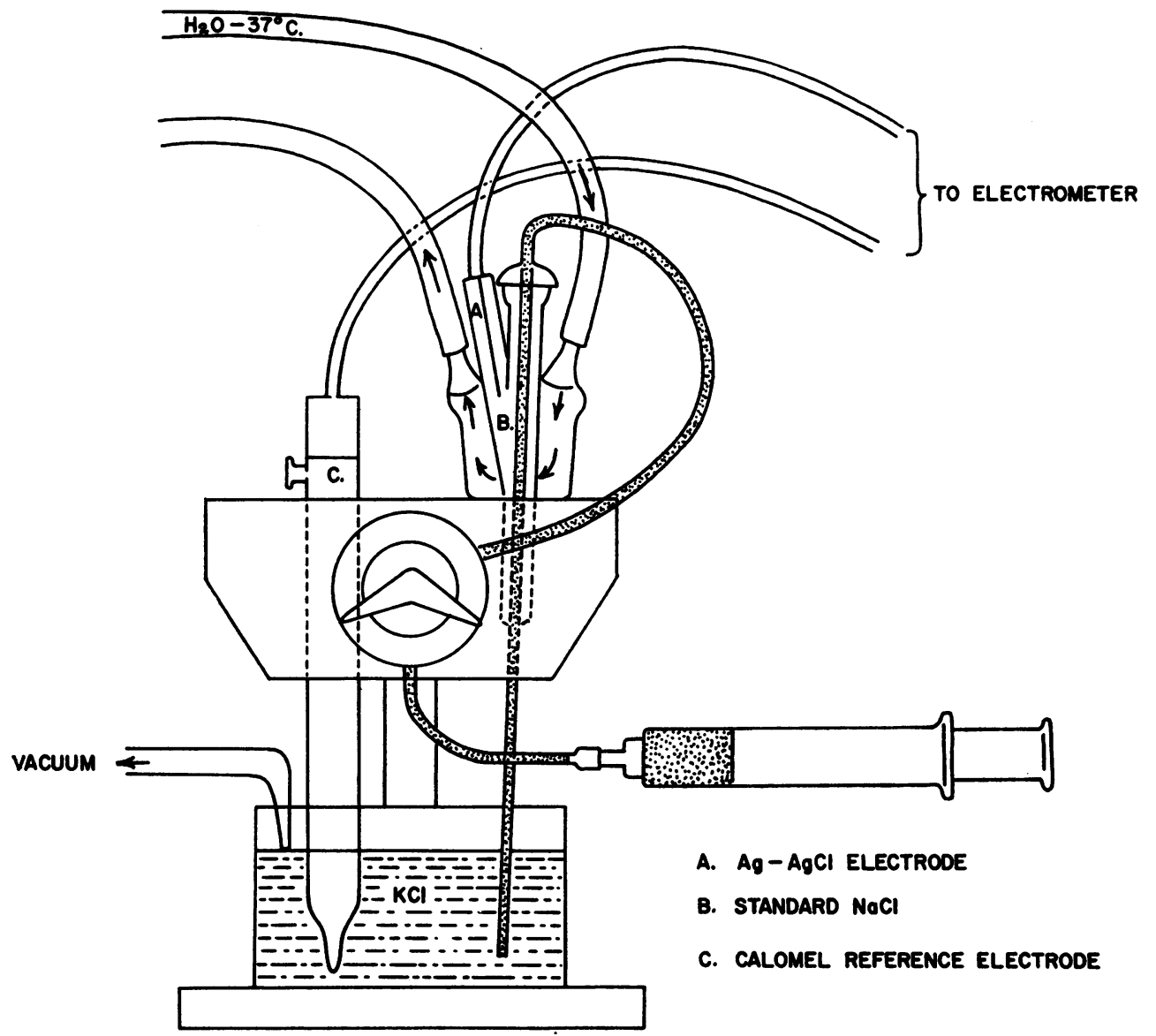

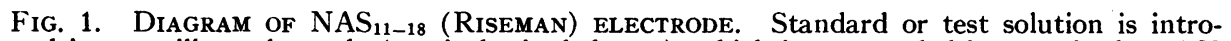
duced into capillary electrode (vertical stippled area), which is surrounded by standard $0.05 \mathrm{~N}$ $\mathrm{NaCl}$ solution (B) containing $\mathrm{Ag}-\mathrm{AgCl}$ wire lead (A). Constant temperature is maintained by a circulating water enclosure. Excess test solution enters saturated $\mathrm{KCl}$ reservoir, the level of which is kept constant by vacuum. A fiber-type calomel half-cell (C) serves as reference.

tenfold change in ion activity would be about $61.7 \mathrm{mv}$ at $37^{\circ} \mathrm{C}$ (i.e., $2.3 R T / n F$ ). Theoretically, therefore, the same change in potential should be registered whether ion activity changes from $0.1 \mathrm{mEq}$ per $\mathrm{L}$ to $0.2 \mathrm{mEq}$ per $\mathrm{L}$, or from 100 $\mathrm{mEq}$ per $\mathrm{L}$ to $200 \mathrm{mEq}$ per $\mathrm{L}$.

Equation 1, which applies to one species of ion in solution, has been elaborated upon by Eisenman and associates (3) to yield a precise description of the glass electrode potential in mixtures of any two univalent cations, represented by the empirical equation:

$$
\begin{aligned}
& E=E^{0}+\frac{2.3 R T}{n F} \log _{10}\left[\left(A^{+}\right)^{1 / n A B}\right. \\
& \left.+k_{A B} B^{1 / n} A B\left(B^{+}\right)^{1 / n_{A B}}\right]^{n_{A B}},
\end{aligned}
$$

where $k_{A B}$ and $n_{A B}$ are empirical constants for a given glass composition and cation pair $\left(A^{+}\right.$ and $B^{+}$). With sodium-sensitive glasses in solutions containing $\mathrm{Na}^{+}-\mathrm{K}^{+}-\mathrm{H}^{+}$mixtures, $k_{\mathrm{NaK}}$ was found to vary with $\mathrm{pH}$, approaching a constant value at low hydrogen ion concentration. This latter coefficient, $k_{A B}$, may be thought of as an expression of the "relative sensitivity" of a particular glass electrode for a given pair of ions (3), i.e., how well the electrode "sees" one cation in preference to another. The value of $k_{A B}$ may be conveniently determined by taking e.m.f. measurements at two different concentrations of one ion in a constant concentration of the other and solving the simultaneous equations. Thus, a value of $k_{\mathrm{NaK}}$ of 0.01 signifies that the electrode "sees" sodium ion $\left(A^{+}\right)$ one hundred times as well as potassium $\left(B^{+}\right)$, or that $0.01 \mathrm{M} \mathrm{Na}^{+}$would register a potential equal to that produced by $1.0 \mathrm{M} \mathrm{K}^{+}$. 
With the glass electrode, it is the activity (a) of an ion which is measured, representing the product of an appropriate activity coefficient $(\gamma)$ and ionic concentration (13):

$$
a_{\mathrm{Na}^{+}}=C_{\mathrm{Na}} \cdot \gamma_{\mathrm{Na}^{+}} \text {. }
$$

Since the activity coefficient cannot be determined for a single ion species, $\gamma_{\mathrm{Na}^{+}}{ }^{+}$refers to the mean coefficient, which is dependent upon the accompanying anion in the solution. In very dilute solutions it is generally satisfactory to assume that the activity of an ion is equal to its concentration, i.e., $\gamma=1$. In more concentrated solutions, activity coefficients are related to the ionic strength of the solution (14). At ionic strengths near $0.01 \mathrm{M}$, the activity coefficient may be calculated by a refined form of the Debye-Hückel equation (15). In order to express electrode data obtained from biological fluids in terms of concentration, it is necessary to know the appropriate activity coefficient. This, in turn, depends upon the ionic strength of the solution and the temperature at which the determination is made.

\section{MATERIALS AND METHODS}

Samples of urine, serum, whole blood, and plasma were obtained from normal hospital personnel. Urine, serum, and CSF were obtained from hospitalized patients with a variety of diseases. The CSF samples had been collected over a period of several months and stored at $-10^{\circ} \mathrm{C}$ prior to analysis. Otherwise, all analyses were performed on the day of sample collection.

The determination of sodium activity was made with a capillary electrode composed of Eisenman's $\mathrm{NAS}_{11-18}$ glass $^{1}\left(\mathrm{Na}_{2} \mathrm{O}, 11\right.$ moles per $100 \mathrm{ml} ; \mathrm{Al}_{2} \mathrm{O}_{3}, 18$ moles per 100 $\mathrm{ml} ; \mathrm{SiO}_{2}, 71$ moles per $100 \mathrm{ml}$ ), using a $\mathrm{KCl}$ salt bridge with a Metrohm fiber-type calomel half-cell as the reference electrode. A diagram of this electrode set-up, referred to as the "Riseman electrode," is shown in Figure 1 and is essentially a modification of a blood $\mathrm{pH}$ electrode. The $\mathrm{NAS}_{11-18}$ glass was a capillary tube (o.d., 1.0 to $1.5 \mathrm{~mm}$; i.d., 0.5 to $1.0 \mathrm{~mm}$; wall thickness about $0.25 \mathrm{~mm}$ ) surrounded by a solution of $0.05 \mathrm{~N} \mathrm{NaCl}$ containing a central $\mathrm{Ag}-\mathrm{AgCl}$ lead. The volume of unknown or standard solution required for analysis was less than $0.5 \mathrm{ml}$, and no dilution of the sample was necessary.

For comparison, sodium activity was also determined in 36 urines by means of an immersion (Haber bulb) electrode composed of lithium aluminum silicate glass of unknown composition, obtained from Beckman Instruments Co. (experimental electrode no. $78178 \mathrm{~V}$ ). A Beckman fiber-

1 Supplied by Riseman Development Laboratory, Cambridge, Mass. type calomel half-cell was used as reference. Both electrodes were immersed in a beaker containing the sample, surrounded by a constant temperature water bath. The volume of sample thus required was about $20 \mathrm{ml}$, and mixing was achieved by a magnetic stirrer.

All potentiometric measurements were made with a Riseman Development Laboratory pH-meter, model MV-1. This is a null balance, chopper amplifier meter with separate inputs for two different $\mathrm{pH}$ or cation-sensitive electrodes, and can be read directly on a vernier dial to $0.001 \mathrm{pH}$ unit or $\pm 0.1 \mathrm{mv}$. Continuous readings over a range of $10 \mathrm{pH}$ units or 1.0 volt may be achieved. Instrument drift is less than $50 \mu \mathrm{v}$ per hour, noncumulative. All determinations of sodium activity were made at $37^{\circ} \mathrm{C}$ with a Haake model $\mathrm{F}$ constant temperature water bath. This temperature was selected so that activity coefficients thus derived could be applied by others in in vivo experiments with glass electrodes.

Calibration of the electrodes was made with $0.010 \mathrm{~N}$, $0.050 \mathrm{~N}$, and $0.100 \mathrm{~N} \mathrm{NaCl}$ standards with assumed sodium activities at $37^{\circ} \mathrm{C}$ of $9.0 \mathrm{mEq}$ per $\mathrm{L}, 40.7 \mathrm{mEq}$ per $\mathrm{L}$, and $77.0 \mathrm{mEq}$ per $\mathrm{L}$, respectively. These latter values were calculated from the Debye-Hückel expression (15). These same standards were also used each day for calibration of the flame photometer.

Although the output signal from the electrometer may be readily amplified and recorded on a moving chart, recalibration necessitated by slight drifts in standard curves makes the calculations somewhat tedious and time consuming. To facilitate the direct calculation of activities, we have constructed a "cation activity board." A large sheet of semilog graph paper is mounted on a plywood board. Sliding over this is a Plexiglas transparent rule with a finely etched line on the under surface; the slope of the rule is adjustable. Millivolt potential (abscissa) is plotted against ionic activity and the slope of the standard curve adjusted. This slope is remarkably constant during the course of a day, but may vary as much as $1.5 \mathrm{mv}$ from day to day. Although the slope of the standard curve is constant for any given day, the entire curve may shift several millivolts. For this reason, the potential of a standard $\mathrm{NaCl}$ solution $(0.050 \mathrm{~N})$ has been measured between each determination of activity in the unknown sample. Such shifts in the standard curve are easily adjusted by sliding the Plexiglas rule so that the millivolt reading of the standard corresponds to the activity of the standard, in this case, $40.7 \mathrm{mEq}$ per $\mathrm{L}$. Sodium activity in the unknown is then read directly from the graph. The entire operation requires only a few seconds, and the need for repeated drawings of standard curves is completely eliminated.

Regarding the properties of the $\mathrm{NAS}_{11-18}$ glass electrode, our data concerning the selectivity constant $k_{\mathrm{AB}}$ are in agreement with those of Eisenman and associates (3), in that there is somewhat greater selectivity for sodium over potassium at high $\mathrm{pH}$. The selectivity of our particular glass is approximately $100 / 1$ at $\mathrm{pH} 7\left(k_{\mathrm{NaK}}=0.01\right)$. Although $k_{\mathrm{AB}}$ appears to vary also with temperature and preferred ion concentration (8), this is probably of no great significance for sodium determinations in biological 


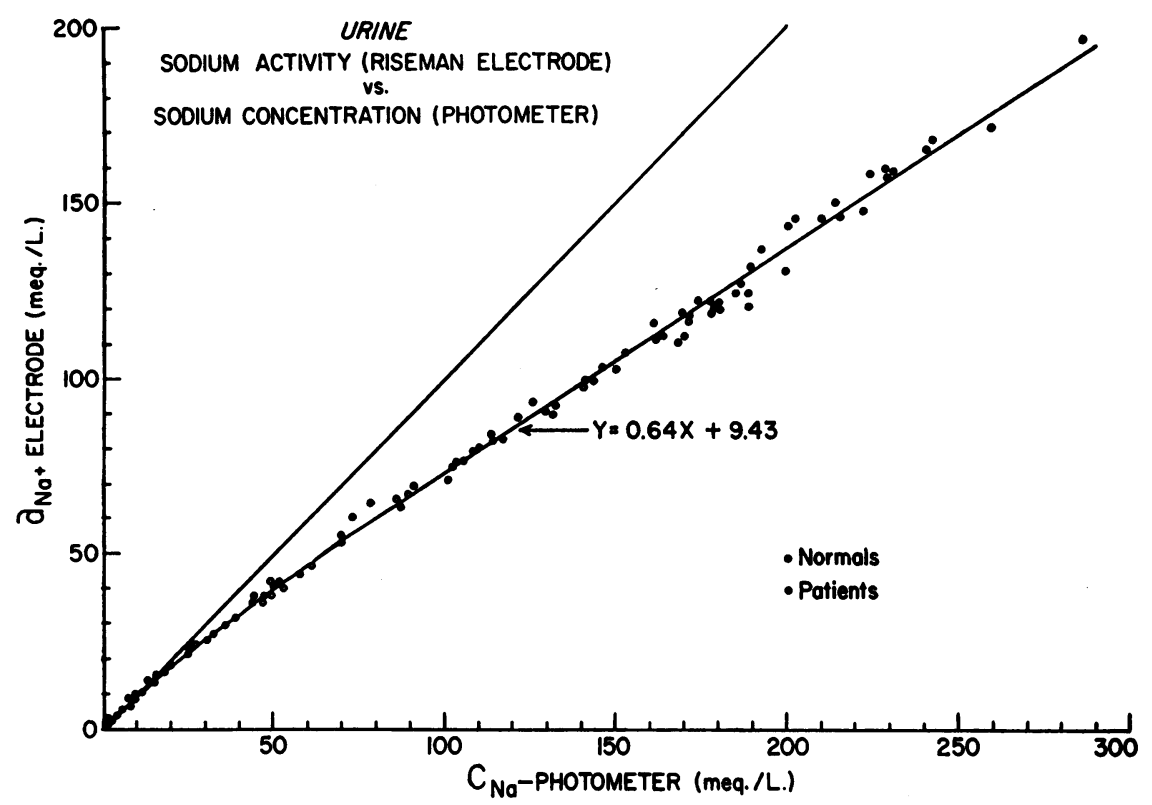

Fig. 2. Comparison OF SOdiUm aCtivities (NAS ${ }_{11-18}$ EleCtrode) With SimultaneOUSLY OBTAINED CONCENTRATION (FLAME PHOTOMETER) VALUES IN 104 URINES Deviation of activity measurements from the $1: 1$ slope line is evident at concentrations above $15 \mathrm{mEq}$ per $\mathrm{L}$, with re-establishment of linearity at concentrations above 70 mEq per $L$.

fluids. The NAS ${ }_{11-18}$ glass is 15 to 20 times more sensitive to hydrogen ion than to sodium ion, but no appreciable hydrogen error is present with sodium concentrations encountered over the physiologic $\mathrm{pH}$ range. Even in urines at $\mathrm{pH} 4.5$, the "hydrogen error" would be less than 1 $\mathrm{mEq}$ per L. These same considerations also apply to the Beckman lithium analog glass used in some of the experiments, although the selectivity of this glass for $\mathrm{Na}^{+}$over $\mathrm{K}^{+}$is somewhat greater than that of the $\mathrm{NAS}_{11-18}$ composition $\left(k_{\mathrm{NaK}}<0.01\right)$. Neither the $\mathrm{NAS}_{11-18}$ nor the Beckman lithium glass showed evidence of anion sensitivity.

All determinations of sodium activity were compared with sodium concentration levels obtained simultaneously by means of a Baird Associates model DB-4 flame photometer. Both the electrode and photometer measurements were made in duplicate, and most of the photometry was performed by one technician. The average difference between duplicate determinations of sodium concentration with the flame photometer for urine, CSF, and serum was $0.8 \mathrm{mEq}$ per $\mathrm{L}$, and the average difference between

TABLE I

Variability of replicate sodium determinations

\begin{tabular}{|c|c|c|c|c|c|c|}
\hline & \multicolumn{3}{|c|}{$\begin{array}{l}\text { Photometer } \\
\text { (concentration) }\end{array}$} & \multicolumn{3}{|c|}{$\begin{array}{l}\text { Electrode } \\
\text { (activity) }\end{array}$} \\
\hline & $\begin{array}{l}\text { Urine } \\
(42)\end{array}$ & $\underset{(34)}{\text { Serum }}$ & $\underset{(34)}{\text { CSF* }}$ & $\begin{array}{c}\text { Urine } \\
(42)\end{array}$ & $\underset{(34)}{\text { Serum }}$ & $\begin{array}{l}\text { CSF } \\
\text { (34) }\end{array}$ \\
\hline $\begin{array}{l}\text { Mean } \\
2 \text { SD }\end{array}$ & $\begin{array}{r}109.8 \\
2.34\end{array}$ & $\begin{array}{l}141.5 \\
2.07\end{array}$ & $\begin{array}{l}141.7 \\
2.25\end{array}$ & $\begin{array}{r}77.6 \\
0.87\end{array}$ & $\begin{array}{c}109.8 \\
0.42\end{array}$ & $\begin{array}{r}105.4 \\
0.96\end{array}$ \\
\hline
\end{tabular}

* Cerebrospinal fluid. duplicate activity measurements with the electrode was $0.3 \mathrm{mEq}$ per L. A more precise estimate of replicate variability was calculated by analysis of variance (Table I). The indicated values (2 SD) represent the $95 \%$ confidence limit for the true value of any given individual sample. Thus, for a single photometer value of $100.0 \mathrm{mEq}$ per $\mathrm{L}$ in urine, the true value would, with $95 \%$ confidence, be between $97.66 \mathrm{mEq}$ per $\mathrm{L}$ and $102.34 \mathrm{mEq}$ per $\mathrm{L}$. The variability between duplicate determinations with the electrode was about one-half that with the photometer, with serum showing the least variability by both methods.

In order to conserve space, individual subject data, except for whole blood and plasma, are not included in tabular form in the present paper, but are available from the authors upon request.

\section{Urine}

RESULTS

A. Group I. Sodium activity was determined in 64 urines from 54 normal subjects and in 40 urines from hospitalized patients. Sodium concentration, as determined by flame photometry, ranged from $26.8 \mathrm{mEq}$ per $\mathrm{L}$ to $286.5 \mathrm{mEq}$ per $\mathrm{L}$ in the normal group, and from $0.1 \mathrm{mEq}$ per $\mathrm{L}$ to $193.0 \mathrm{mEq}$ per $\mathrm{L}$ in urines from patients.

When sodium activity $\left(a_{\mathrm{Na}}\right)$ was plotted against the simultaneously obtained flame concentration $\left(C_{\mathrm{NaP}_{\mathrm{P}}}\right)$, a linear function $Y=0.64 X$ +9.43 was obtained for urines with sodium 


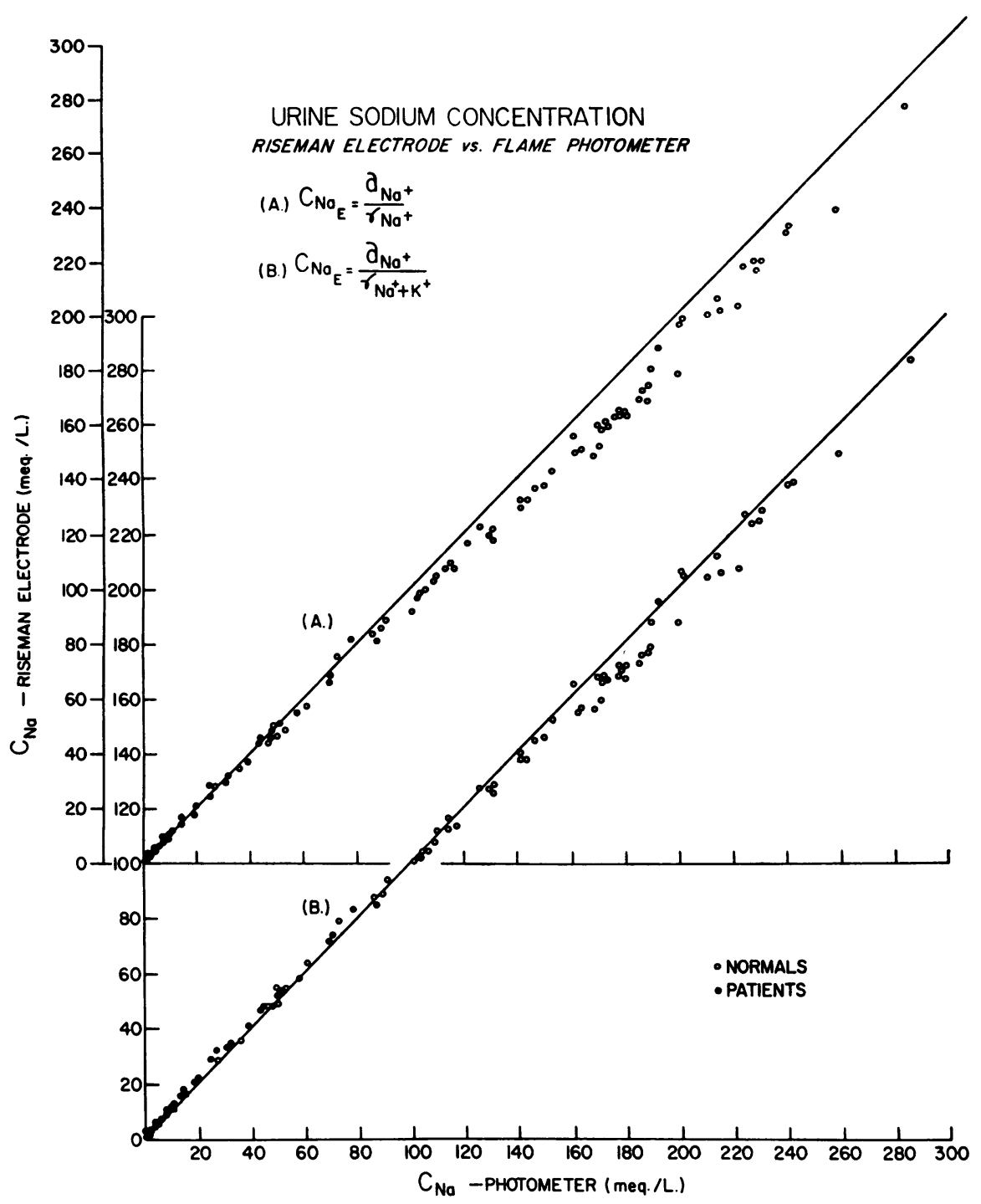

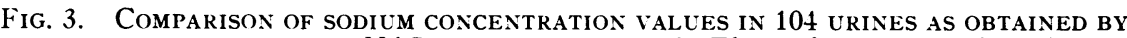
FLAME PHOTOMETRY AND THE NAS ${ }_{11-18}$ ELECTRODE. A. Electrode concentrations $\left(C_{\mathrm{NaE}}\right)$ have been calculated from activity coefficients for $\mathrm{NaCl}$ in aqueous solution according to the

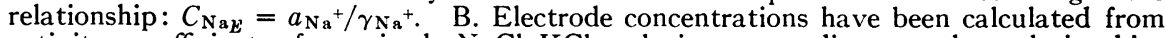
activity coefficients for mixed $\mathrm{NaCl}-\mathrm{KCl}$ solutions according to the relationship: $C_{\mathrm{Na} E}=\gamma \mathrm{Na}^{+}+\mathrm{K}^{+} / a_{\mathrm{Na}^{+}}$.

concentrations above about $15 \mathrm{mEq}$ per $\mathrm{L}$ (Figure 2). In urines containing 6 to 15 $\mathrm{mEq}$ per $\mathrm{L}$, the measured activity was essentially equal to concentration. At sodium concentrations below $6 \mathrm{mEq}$ per $\mathrm{L}$, the measured activity was usually greater than the corresponding concentration value, undoubtedly related to potassium error in the glass. (Thus, for a glass with $k_{\mathrm{NaK}}=0.01$, a urine containing $1 \mathrm{mEq}$ per $\mathrm{L}$ sodium and $100 \mathrm{mEq}$ per $\mathrm{L}$ potassium would register a potential equivalent to $2 \mathrm{mEq}$ per $\mathrm{L}$ sodium.)

There appeared to be no intrinsic difference between urines from normal subjects and those from patients; the function $Y=0.64 X+9.43$ describes activity-concentration relationships equally well in both. Also, there was no apparent difference in the behavior of urines with high sodium concentrations and those with low levels. When high-sodium urines were diluted $1: 1$, the 
resulting activities were also accurately represented by the above function.

Protein was present in 12 of the patient urines above, and in 5 of these the proteinuria was marked. Sodium activity in each of these showed no appreciable deviation from the mean activity curve for the group as a whole. The effect of various normal urinary constitutents on sodium activity was also studied. The addition of large amounts of urea or uric acid had no appreciable effect on measured sodium activity. Glucose, when added to urine in concentrations ranging from $2 \%$ to $6 \%$, was found to increase activity measurements somewhat, the average $\Delta a_{\mathrm{Na}}{ }^{+}$being only about $2 \mathrm{mEq}$ per $\mathrm{L}$ with $6 \%$ glucose.

No attempt was made to relate activity measurements to the $\mathrm{pH}$ of urine, since the large number of sample determinations should result in a random $\mathrm{pH}$ distribution over any given sodium concentration interval. Also, if urinary sodium activity could be determined without regard to $\mathrm{pH}$, the usefulness of the electrode would be considerably enhanced.

In order to express electrode activity data in terms of sodium concentration, it was necessary to derive the proper activity coefficients. Activity coefficients $\left(\gamma_{\mathrm{Na}^{+}}\right)$for $\mathrm{NaCl}$ in aqueous solution at $37^{\circ} \mathrm{C}$ were used in an attempt to effect this conversion. These coefficients were calculated according to the Debye-Hückel equation (15) for sodium concentrations up to 100 mEq per L. Above this level, $\gamma_{\mathrm{Na}^{+}}$was extrapolated by a line parallel to standard table values (16) for $\mathrm{NaCl}$ at $25^{\circ} \mathrm{C}$. As may be seen in Figure 3A, sodium concentration values thus obtained by the electrode $\left(C_{\mathrm{Na}_{E}}\right)$ were less than the corresponding photometric values $\left(C_{\mathrm{Nap}}\right)$, particularly with concentrations above $50 \mathrm{mEq}$ per $\mathrm{L}$, indicating that sodium activity coefficients for urine are less than those of aqueous $\mathrm{NaCl}$ solutions. The average deviation from photometric values in 64 normal urines amounted to $-9.7 \mathrm{mEq}$ per $\mathrm{L}$, representing a mean error of $-6.0 \%$. In the group of 40 patient urines, with considerably lower sodium concentrations, the mean deviation, without regard to sign, was only $1.3 \mathrm{mEq}$ per L. Clearly, activity coefficients for aqueous $\mathrm{NaCl}$ solutions could not be applied to high-sodium urines if great precision were required, but would be adequate if only a rough approximation of sodium concentration were needed, or if the sodium concentration were low.

In order to determine the ion primarily responsible for this suppression of sodium activity, the effect of potassium was investigated. Since activity coefficients for $\mathrm{KCl}$ in aqueous solution are somewhat less than those for $\mathrm{NaCl}$ (16), the question arises: To what degree does a given amount of potassium suppress sodium activity? If one assumes that suppression by potassium, with the same charge as sodium but with smaller hydrated ion diameter (17), is identical to that produced by an equivalent amount of $\mathrm{NaCl}$ (allowing for the difference in activity of these ions in pure solution), calculations may be made from interpolation of standard activity coefficient curves. Thus, if a given urine contained $100 \mathrm{mEq}$ per $\mathrm{L} \mathrm{Na}^{+}$, the presence of $100 \mathrm{mEq}$ per $\mathrm{L} \mathrm{K}^{+}$, as determined by photometry, would lower the mean activity coefficient from 0.770 to 0.722 (disregarding the effects of $\mathrm{H}^{+}, \mathrm{NH}_{4}{ }^{+}$, $\mathrm{Ca}^{++}$, etc.). When such activity coefficients were derived for the entire group of urines, sodium concentrations were obtained which agreed more closely with photometric values (Figure 3B). The mean deviation $\left(C_{\mathrm{Na}_{E}}-C_{\mathrm{Na}_{\mathrm{P}}}\right)$ for the group of 64 normal urines, without regard to sign, was $5.2 \mathrm{mEq}$ per $\mathrm{L}$, or about $3.4 \%$. Thus, as might be expected, the suppression of sodium activity in urine, relative to the activity of aqueous $\mathrm{NaCl}$ solutions of equal ionic strength, was primarily related to the presence of potassium, the other major cation in urine. Of course, the derived coefficient $\gamma_{\mathrm{Na}^{+}+\mathrm{K}^{+}}$was of no practical value in interpreting electrode activity data, since a foreknowledge of both sodium and potassium concentrations was required.

An empirical relationship between measured sodium activity and the activity coefficient necessary to achieve correspondency to photometric values was therefore derived for each urine. This empirical coefficient, $\gamma_{u \text { rine, was }}$ calculated by dividing measured activity by the sodium concentration as determined by photometry: $\gamma_{\mathrm{urine}}=a_{\mathrm{Na}^{+}} / C_{\mathrm{Na}_{\mathrm{a}_{P}}}$. A table of mean activity coefficients was then constructed from the resulting mean curve. These coefficients, $\gamma_{u \text { rinex }}$, were then used to calculate the urinary sodium 


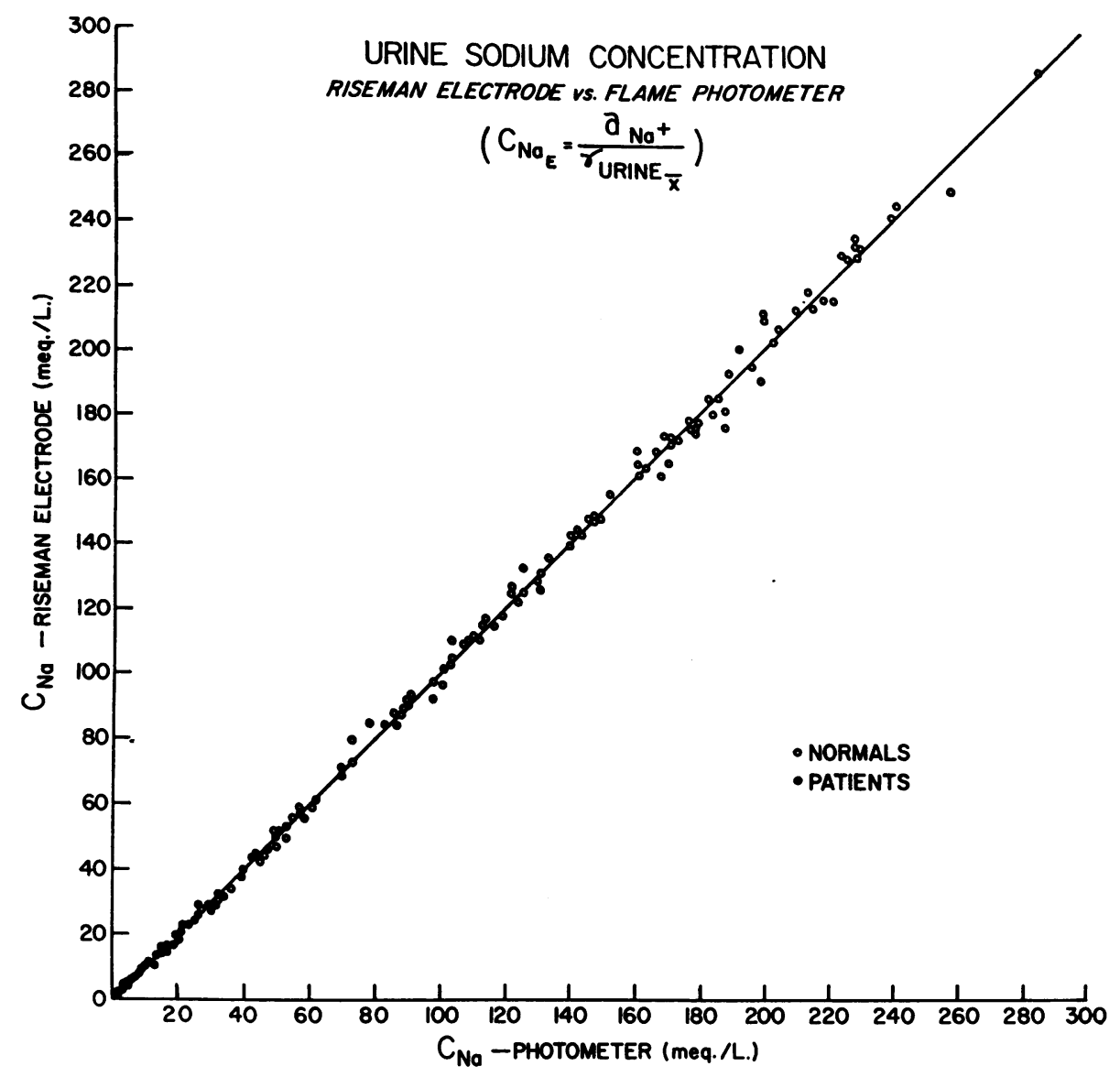

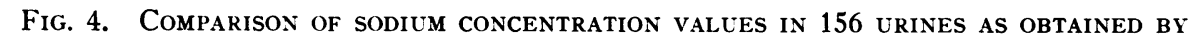
FLAME PHOTOMETRY AND THE NAS $11-18$ ELECTRODE. Electrode concentration values have been calculated from the empirical mean activity coefficient curve according to the relationship: $C_{\mathrm{Na}_{E}}=a_{\mathrm{Na} E} / \gamma_{\text {urine } \bar{x}}$.

concentration $\left(C_{\mathrm{NaE}_{\mathrm{E}}}\right)$ from electrode activity measurements, according to the relationship: $C_{\mathrm{Na}_{E}}=a_{\mathrm{Na}^{+}} / \gamma_{\text {urinex. }}$. The resulting close correlation of these electrode concentrations to the corresponding photometric values is shown in Figure

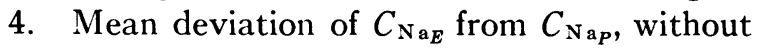
regard to sign, was $3.4 \mathrm{mEq}$ per $\mathrm{L}$, or $2.5 \%$ in the 64 normal urines, and $1.1 \mathrm{mEq}$ per $\mathrm{L}$ in the forty patient urines. Over-all difference for the 104 urines was $2.6 \mathrm{mEq}$ per $\mathrm{L}$.

B. Group II. The usefulness and accuracy of the derived empirical activity coefficients were further tested in an additional 52 urines, including 29 urines from normal subjects and 23 urines from hospitalized patients. The average deviation of the electrode values in these urines from those obtained by photometry was only $2.2 \mathrm{mEq}$ per $\mathrm{L}$, or $2.0 \%$, in the normal subjects and $0.9 \mathrm{mEq}$ per $\mathrm{L}$ in the urines from patients. All of these are also plotted in Figure 4. The mean deviation from photometric values for all group I and group II urines (156 samples) was $2.2 \mathrm{mEq}$ per $\mathrm{L}$. In the 93 normal urines, the average deviation of electrode concentrations from photometric values was $3.1 \mathrm{mEq}$ per $\mathrm{L}$, or $2.3 \%$.

C. Beckman electrode. In order to determine variability in measured sodium activity between two different glasses, activity measurements were also made in 36 of the above urines by means of a lithium aluminum silicate (Beckman) electrode (Figure 5). Activity measurements with the Beckman electrode were usually slightly lower than those obtained with the $\mathrm{NAS}_{11-18}$ glass, but the correlation was quite close $(r=0.998)$. The relation between the two electrode activities could be expressed by the function $Y=0.97 X$ -0.36 . When activity coefficients for the 


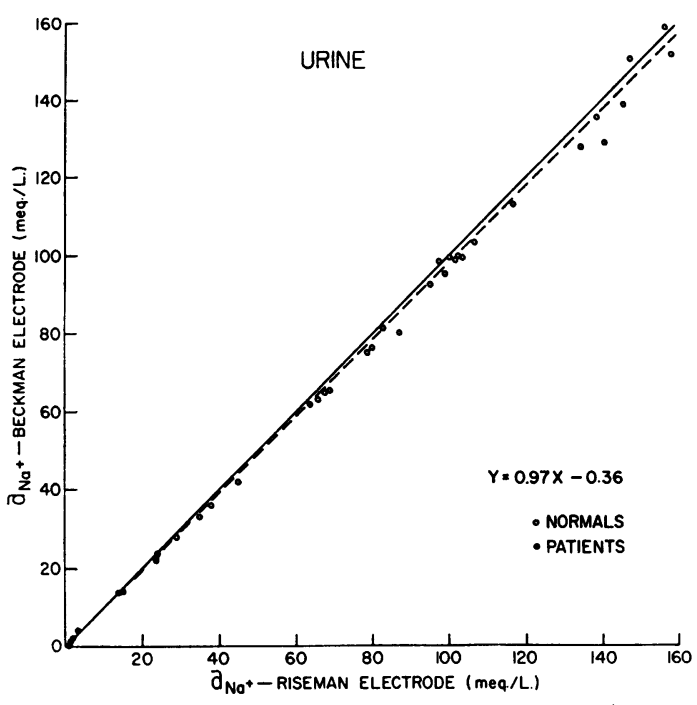

Fig. 5. Comparison OF SODIUM activities SIMUlTANEOUSLY OBTAINED FROM TWO GLASS ELECTRODES AT $37^{\circ} \mathrm{C}$.

$\mathrm{NAS}_{11-18}$ glass were used to convert "Beckman activities" to concentrations, the values thus obtained were low when compared with the photometer. An empirical activity coefficient curve was therefore derived for the Beckman electrodeasdescribed above for the $\mathrm{NAS}_{11-18}$ glass, yielding the hyperbola $Y=0.646+(3.25 / X)$. When the activity coefficients obtained from this function were used to convert activities to concentrations, mean deviation from the photometric values was $3.3 \mathrm{mEq}$ per $\mathrm{L}$, compared with an average error of $1.8 \mathrm{mEq}$ per $\mathrm{L}$ in these same urines with the $\mathrm{NAS}_{11-18}$ glass. The somewhat greater accuracy with the $\mathrm{NAS}_{11-18}$ electrode may, in part, reflect the fact that the activity coefficient curve for this glass had been determined by a larger number of observations and, therefore, with greater certainty.

\section{Serum}

Sodium activity was determined with the $\mathrm{NAS}_{11-18}$ electrode in a total of 104 sera, including sera from 23 normal subjects and 20 individual patients, and 61 pooled sera from patients. The resulting plot of activities against the corresponding photometric values, represented by the linear function $Y=0.748 X+4.11$ $(\mathrm{r}=0.957)$, is shown in Figure 6. The mean activity coefficient for the 23 normal subjects was $0.780 \pm 0.001,^{2}$ which was not significantly different from the mean of $0.774 \pm 0.002$ in the 20 individual patients or from the mean of $0.779 \pm 0.001$ in the 61 pooled sera. The somewhat greater variability in activity coefficients among the latter 2 groups might be expected, since a more extreme concentration range was encountered in these sera.

The appropriate mean activity coefficients $\left(\gamma_{\text {serum }}\right)$, derived from the linear function above, were then used to convert activities to concentrations according to the relationship: $C_{\mathrm{Na}_{E}}=a_{\mathrm{Na}{ }}$ / $\gamma_{\text {serum }_{\tilde{x}}}$. The mean deviation of the concentration values thus obtained from the corresponding photometric values, without regard to sign, was 1.3 $\mathrm{mEq}$ per $\mathrm{L}$ in the entire group, representing an average error of $0.9 \%$.

It should be noted that sodium activities in sera were somewhat higher than those which would be expected in pure aqueous solutions of $\mathrm{NaCl}$ at $37^{\circ} \mathrm{C}$. This discrepancy appeared to be related to the fact that the nonaqueous phase of serum was neglected in the expression of sodium concentration as determined by photometry. When photometric values were expressed in terms of sodium concentration in serum water, resulting serum activity coefficients were somewhat less than those for corresponding aqueous $\mathrm{NaCl}$ solutions. These coeffi-

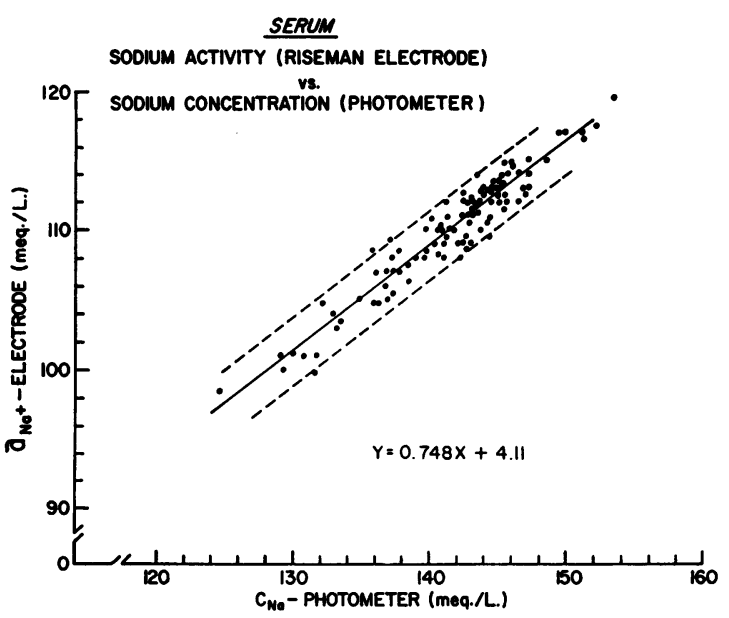

Fig. 6. THE RELATIONSHIP OF SODIUM ACTIVITIES IN 104 SERA, AS DETERMINED WITH THE NAS $_{11-18}$ ELECTRODE, TO SIMULTANEOUSLY OBTAINED CONCENTRATION (PHOTOMETER) VALUES. The solid line is the group mean; the dotted lines represent the $95 \%$ confidence limit ( $\pm 2 \mathrm{SD}$ ).

21 standard error of the mean. 


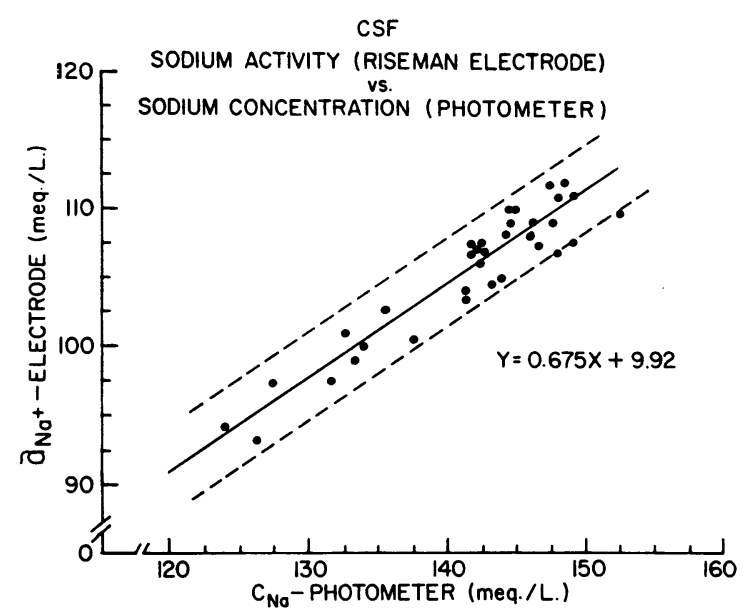

Fig. 7. ThE RELATIONSHip OF SODIUM ACtivities IN CEREBROSPINAL FLUID, AS DETERMINED WITH THE NAS N1-18 $_{11}$ ELECTRODE, TO SIMULTANEOUSLY OBTAINED CONCENTRATION (PHOTOMETER) VALUEs. The solid line is the group mean; the dotted lines represent the $95 \%$ confidence limit $( \pm 2 \mathrm{SD})$.

cients correlated very closely when the average serum water content was assumed to be $96 \%$ by volume $(0.747$ for serum vs 0.750 for $\mathrm{NaCl}$ at a sodium concentration of $140 \mathrm{mEq}$ per L).

\section{Cerebrospinal fluid}

The $\mathrm{NAS}_{11-18}$ electrode was used to determine sodium activity in the CSF of 26 patients and in 8 pooled samples from other patients. The resulting plot of activities against simultaneously obtained photometric concentrations is shown in Figure 7 and is represented by the function $Y=0.675 X+9.92$. Mean activity coefficients for CSF were quite close to those for pure $\mathrm{NaCl}$ solutions $(0.745$ for $\mathrm{CSF}$ vs 0.750 for $\mathrm{NaCl}$ at $140 \mathrm{mEq}$ per L sodium concentration), and the mean activity coefficient for the entire group of CSF determinations was $0.744 \pm 0.002$. With mean coefficients $\left(\gamma_{\mathrm{CSF}_{\bar{x}}}\right)$ from the above linear function, the average deviation of electrode concentration values from corresponding photometric values, without regard to sign, was 2.2 $\mathrm{mEq}$ per $\mathrm{L}$.

\section{Whole blood and plasma}

In order to determine the effect of whole blood on electrode potential, activity measurements were made in samples of fresh blood from nine normal subjects and compared with the activities simultaneously obtained in the plasma from these same specimens (Table II). Heparin, containing about $440 \mathrm{mEq}$ per $\mathrm{L}$ sodium, was used as anticoagulant $(0.2 \mathrm{ml}$ heparin in $20 \mathrm{ml}$ blood), and accounts for the high sodium levels encountered in the analyses.

Whole blood activities were quite close to those obtained from the corresponding plasmas, with a mean difference, without regard to sign, of $0.9 \mathrm{mEq}$ per L. Accordingly, there was no significant difference in mean activity coefficients of $0.757 \pm 0.003$ and $0.754 \pm 0.003$ in whole blood and plasma, respectively, uncorrected for nonaqueous phases.

\section{DISCUSSION}

The subject of cation-selective glass electrodes and their mode of operation has recently been extensively reviewed by Eisenman (11). From the present work, a few comments seem warranted in regard to the use of such electrodes in biological systems.

The outstanding advantage of electrodes over other physical methods of measurement lies in the fact that the activity of these ions may be directly determined. There is little doubt that ionic activity has greater physiologic significance than ionic concentration, and it seems inevitable that medical research will become more and more oriented towards activity, particularly as more specific cation-selective glasses become available. This seems especially true for di-

TABLE II

Whole blood and plasma sodium activities from nine normal subjects

\begin{tabular}{|c|c|c|c|c|c|}
\hline \multirow[b]{2}{*}{ Subject } & \multirow[b]{2}{*}{$C_{\mathrm{Na}_{\mathrm{P}}} *$} & \multicolumn{2}{|c|}{ Whole blood } & \multicolumn{2}{|c|}{ Plasma } \\
\hline & & $a \mathrm{Na}^{+}$ & $\gamma_{\text {Blood }}$ & $a_{\mathrm{Na}^{+}}{ }^{+}$ & $\gamma_{\text {Plasma }}$ \\
\hline & $m E q / L$ & \multicolumn{2}{|c|}{$m E q / L$} & \multicolumn{2}{|c|}{$m E q / L$} \\
\hline D.A. & 158.6 & 118.0 & 0.744 & 119.5 & 0.754 \\
\hline R.W. & 151.3 & 115.5 & 0.763 & 114.5 & 0.757 \\
\hline R.S. & 159.0 & 120.5 & 0.758 & 119.8 & 0.753 \\
\hline J.R. & 153.8 & 118.2 & 0.768 & 117.5 & 0.764 \\
\hline M.S. & 157.3 & 118.0 & 0.750 & 117.8 & 0.749 \\
\hline F.D. & 156.0 & 118.5 & 0.760 & 118.8 & 0.762 \\
\hline H.A. & 154.0 & 117.8 & 0.765 & 117.5 & 0.763 \\
\hline R.L. & 160.0 & 120.0 & 0.750 & 118.5 & 0.741 \\
\hline D.W. & 161.6 & 122.5 & 0.758 & 120.5 & 0.746 \\
\hline Mean & 156.8 & 118.8 & 0.757 & 118.3 & 0.754 \\
\hline SE & & 0.66 & 0.003 & 0.59 & 0.003 \\
\hline
\end{tabular}

* Sodium concentration (photometer). 
valent ions, most notably $\mathrm{Ca}^{++}$and $\mathrm{Mg}^{++}$, where the ionized fraction is recognized as the physiologically active species. In this regard, it is often convenient to express electrode data in terms of the negative logarithm of the activity, as in $\mathrm{pH}$ measurements. Thus, a sodium or potassium activity of $1.0 \mathrm{mEq}$ per $\mathrm{L}(0.001 \mathrm{~N})$ would be represented by $\mathrm{pNa}^{+}=3.0$ or $\mathrm{pK}^{+}=3.0$, respectively. In conjunction with Eisenman (18), we suggest that + superscripts be used for such notations in order to avoid confusion with the more commonly used $\mathrm{pK}$, representing the negative logarithm of a dissociation constant.

Other advantages of glass electrodes relate to their ease of handling and operation, reproducibility, and rapidity of response. Friedman and associates $(5,6)$ have established their usefulness in the continuous in situ or in vivo monitoring of ionic activity, and Hinke (7) has developed electrodes for the direct measurement of intracellular ionic activity. It should be emphasized that, in the present work, sodium activity has been directly determined in urine and other extracellular fluids without the necessity of dilution or other alteration of the specimen. Equilibrium potentials are usually obtained within 3 minutes, although in urines with very low sodium activity ( $<1 \mathrm{mEq}$ per $\mathrm{L}$ ) an additional 3 to 5 minutes may be required for great accuracy.

It has been shown that the activity response of two different sodium-sensitive electrodes in body fluids is linearly related to sodium concentration as determined by flame photometry. When expressing electrode data in terms of concentration instead of activity, the fundamental problem is, therefore, the derivation of appropriate activity coefficients for each fluid under investigation. This has been done for $\mathrm{NAS}_{11-18}$ glass in urine, serum, CSF, whole blood, and plasma, and also for a lithium aluminum silicate glass in urine. Although the correlation between activity measurements with two separate glasses is quite close, it seems advisable, for very precise work, to construct empirical activity coefficient curves for any given glass composition and for any given fluid.

Activity coefficients for CSF, whole blood, and plasma do not vary greatly from the corre- sponding coefficients for $\mathrm{NaCl}$ in pure aqueous solution. The latter coefficients may, therefore, be useful for the rough approximation of sodium concentration in these fluids. These findings would also seem to indicate that the effect of erythrocytes and protein on electrode response is negligible. When corrections were made for the nonaqueous phase of serum, activity coefficients also corresponded closely with those for pure $\mathrm{NaCl}$ solutions. The serum data must be interpreted with caution, however, since a rather narrow concentration range was encountered in the present study. For urine, it has been shown that the depression of sodium activity below that for corresponding aqueous solutions of $\mathrm{NaCl}$ is due primarily to the presence of potassium ion. Glucose in high concentration tended to increase sodium activity slightly, while urea and uric acid appeared to have little or no effect. Again, the use of pure $\mathrm{NaCl}$ activity coefficients would be useful if only a rough approximation of sodium concentration were required.

Although the average variability between electrode activity measurements and flame concentration measurements is not great, in some urines it appears to be real. Undoubtedly, part of this variability is related to hydrogen ion effects and to errors in measurement for both the electrode and photometer. In an occasional urine, however, the measured sodium activity may be consistently higher or lower than that expected from the mean derived curve. This probably represents "biologic variability" in the sense that the total ionic strength of two urines may vary considerably even though their sodium concentrations are identical. Although the difference is usually small, this possible source of error should be considered in situations where very precise work is required.

It is clear that glass electrodes of the sensitivity used in the present study are quite adequate for work with biological fluids. The usefulness of such electrodes will undoubtedly increase as other specific cation-sensitive glasses become available. In addition, it may be possible to develop anion-sensitive glasses. Work is currently in progress with a potassiumselective glass which is also quite sensitive to ammonium ion. Preliminary data indicate that 
the measurement of urinary potassium is feasible with this technique, and it may be possible to determine urinary ammonia as a by-product. The selectivity of this particular glass for potassium is too low for accurate determination in serum, but this problem should be solved when more selective glasses become available.

We believe that electrodes may find considerable usefulness as a routine clinical or research tool. This might readily be accomplished by the construction of a battery of electrodes, including those selective for $\mathrm{H}^{+}, \mathrm{K}^{+}, \mathrm{Na}^{+}$, and $\mathrm{Ca}^{++}$. By the introduction of a sample into each electrode simultaneously, with a common reference, the time required for equilibration would be no greater than that for one of the electrodes. The resulting activities could easily be monitored through appropriate recording devices, with the achievement of virtual automation.

Finally, perhaps the greatest usefulness of such electrodes will be in the determination of divalent ionic activity, particularly $\mathrm{Ca}^{++}$and $\mathrm{Mg}^{++}$. As noted by Eisenman (11), the monovalentsensitive glasses (such as the $\mathrm{NAS}_{11-18}$ elec trode) respond to doubly charged cations with the expected slope of $R T / 2 F$ in pure solutions, but their sensitivity for such ions is so low that presently available glasses are of little use in the determination of divalent ions in biological materials. Recently, however, Garrels, Sato, Thompson, and Truesdell (19) have discovered the existence of a class of glasses having important sensitivity to doubly charged cations such as $\mathrm{Ca}^{++}$. Thus far, all of the glasses studied in this laboratory which have shown reasonable calcium sensitivity have also been quite sensitive to ions in the monovalent series. The determination of calcium activity in biological materials may, therefore, require very accurate measurement of sodium and potassium, and perhaps hydrogen and ammonium activities.

\section{SUMMARY}

Until recently, there has been no method for the direct determination of activity of alkali ions in biological fluids, physiological data having been expressed solely in terms of concentration. In the present paper, the mathematical and electrochemical techniques for the determination of $\mathrm{pH}$ have been applied to the potentiometric determination of sodium ion in body fluids by selective glass electrodes. The method is rapid, highly reproducible, and requires no dilution or alteration of the sample. Sodium activity in urine, serum, cerebrospinal fluid, whole blood, and plasma was linearly related to sodium concentration as determined by flame photometry. Electrode data could also be expressed in terms of concentration by derivation of appropriate empirical activity coefficients for each fluid. Results agreed with flame photometer values within about $2 \%$. Protein, erythrocytes, urea, and uric acid had no apparent adverse effect on electrode potential.

\section{ACKNOWLEDGMENT}

We wish to express our appreciation to Miss Susan J. Gordon and Dr. Hugo Muench for their assistance in the statistical analyses.

\section{REFERENCES}

1. Moore, E. W., and D. W. Wilson. The determination of sodium in body fluids by means of the glass electrode (abstract). J. clin. Invest. 1962, 41, 1385.

2. Isard, J. O. Alkali ion determinations by means of glass electrodes. Nature (Lond.) 1959, 184, 1616.

3. Eisenman, G., D. O. Rudin, and J. U. Casby. Glass electrode for measuring sodium ion. Science 1957, $126,831$.

4. Bower, C. A. Determination of sodium in saline solutions with a glass electrode. Soil Sci. Amer. Proc. 1959, 23, 29.

5. Friedman, S. M., J. D. Jamieson, M. Nakashima, and C. L. Friedman. Sodium- and potassium-sensitive glass electrodes for biological use. Science 1959, 130, 1252.

6. Friedman, S. M., J. D. Jamieson, J. A. M. Hinke, and C. L. Friedman. Use of glass electrode for measuring sodium in biological systems. Proc. Soc. exp. Biol. (N. Y.) 1958, 99, 727.

7. Hinke, J. A. M. Glass micro-electrodes for measuring intracellular activties of sodium and potassium. Nature (Lond.) 1959, 184, 1257.

8. Wall, R. A., and E. W. Moore. Glass electrode response as a function of temperature, $\mathrm{pH}$ and ionic composition. In preparation.

9. Glasstone, S., and D. Lewis. Elements of Physical Chemistry. Princeton, D. Van Nostrand, 1960, p. 551.

10. Dole, M. The Glass Electrode, New York, John Wiley \& Sons, 1941.

11. Eisenman, G. Cation selective glass electrodes and their mode of operation. Biophys. J. 1962, part 2, 2, 259. 
12. Leonard, J. E. Glass electrodes for the direct measurement of sodium ion activity in aqueous solutions. Beckman Instruments Co. Reprint No. R-6148, April 1960.

13. Gold, V. pH Measurements. London, Methuen, 1956.

14. Klotz, I. M. Chemical Thermodynamics. Englewood Cliffs, N. J., Prentice-Hall, 1960, p. 310.

15. Ibid. p. 329 .
16. Handbook of Chemistry and Physics, 42nd ed., C. D. Hodgman, Ed. Cleveland, Chemical Rubber Publishing Co., 1960, p. 2611.

17. Klotz, I. M. Chemical Thermodynamics. Englewood Cliffs, N. J., Prentice-Hall, .1960, p. 331.

18. Eisenman, G. Personal communication.

19. Garrels, R. M., M. Sato, M. E. Thompson, and A. H. Truesdell. Glass electrodes sensitive to divalent cations. Science 1962, 135, 1045.

\section{ANNOUNCEMENT OF MEETINGS}

THE AMERICAN FEDERATION FOR CLINICAL RESEARCH will hold its Twentieth Annual Meeting in Atlantic City, N. J., at the Casino Theatre on the Steel Pier on Sunday, April 28, 1963, at 9:00 a.m. Joint sectional meetings with The American Society for Clinical Investigation will be held on Sunday afternoon at Chalfonte-Haddon Hall, and additional meetings sponsored by The American Federation for Clinical Research will be held there on Sunday evening.

THE AMERICAN SOCIETY FOR CLINICAL INVESTIGATION, INC., will hold its Fifty-fifth Annual Meeting in Atlantic City, N. J., on Monday, April 29, at 9:00 a.m., at the Casino Theatre on the Steel Pier and in simultaneous programs sponsored with The American Federation for Clinical Research on Sunday afternoon, April 28, in Chalfonte-Haddon Hall.

THE ASSOCIATION OF AMERICAN PHYSICIANS will hold its Seventy-sixth Annual Meeting in Atlantic City, N. J., at the Casino Theatre on the Steel Pier on Tuesday, April 30, at 9:30 a.m., and in the Vernon Room, Chalfonte-Haddon Hall, on Wednesday, May 1, at 9:30 a.m.

THE AMERICAN SOCIETY FOR CLINICAL NUTRITION will hold its Third Annual Meeting in Atlantic City, N. J., at the Colton Manor Hotel on Saturday, April 27, from 1:00 to $5: 00$ p.m. 